\title{
ANALISIS KEPUASAN KONSUMEN DI RUMAH SAKIT RAWAMANGUN JAKARTA TIMUR
}

\author{
Lania Muharsih \\ Email: lania.muharsih@ubpkarawang.ac.id
}

Fakultas Psikologi Universitas Buana Perjuangan Karawang

\begin{abstract}
This study aims to analyze consumer satisfaction at Rawamangun Hospital in East Jakarta. The subjects in this study were 98 outpatients. The instrument used in this study was a scale of customer satisfaction that was compiled based on customer satisfaction factors according to Handi Irawan (2003) which included five factors namely product quality, price, service quality, emotional factors, and convenience. It also consist of 20 favorable items. The results of the reliability analysis showed that the scale of consumer satisfaction has a reliability coefficient of 0.809 which means that the scale of consumer satisfaction is reliable. The results showed that there were 46 people or $46.9 \%$ of subjects who had high customer satisfaction in the category, 45 people or $45.9 \%$ of subjects had consumer satisfaction in the medium category, and 7 people or $7.1 \%$ of subjects had consumer satisfaction in the category low. In addition, the main factor that causes customer satisfaction is the convenience factor which contributes $81.9 \%$ to consumer satisfaction.
\end{abstract}

Keywords: Consumer Satisfaction, Rawamangun Hospital.

Abstrak. Penelitian ini bertujuan untuk menganalisis kepuasan konsumen di Rumah Sakit Rawamangun Jakarta Timur. Subyek pada penelitian ini yaitu pasien rawat jalan yang berjumlah 98 orang. Instrumen yang digunakan dalam penelitian ini berupa skala kepuasan konsumen yang disusun berdasarkan faktor-faktor kepuasan konsumen menurut Handi Irawan (2003) yang meliputi lima faktor yaitu faktor kualitas produk, harga, kualitas pelayanan, faktor emosional, dan kemudahan serta terdiri dari 20 item favorable. Hasil analisis reliabilitas menunjukkan bahwa skala kepuasan konsumen memiliki koefisien reliabilitas sebesar 0,809 yang berarti skala kepuasan konsumen ini reliabel. Hasil penelitian menunjukkan bahwa terdapat 46 orang atau $46,9 \%$ subyek yang memiliki kepuasan konsumen pada kategori tinggi, 45 orang atau 45,9\% subyek memiliki kepuasan konsumen pada kategori sedang, dan 7 orang atau 7,1\% subyek memiliki kepuasan konsumen pada kategori rendah. Selain itu, faktor utama yang menimbulkan kepuasan konsumen adalah faktor kemudahan yang memberikan sumbangan sebesar $81,9 \%$ terhadap kepuasan konsumen.

Kata Kunci: Kepuasan Konsumen, Rumah Sakit Rawamangun.

1 | Psychophedia Jurnal Psikologi Universitas Buana Perjuangan Karawang 


\section{Pengantar}

Setiap individu di dalam kehidupannya membutuhkan pelayanan jasa kesehatan. Individu yang hidup di dunia ini tentunya terkadang mengalami keadaan tubuh yang lemah dan tidak dapat hidup sempurna seperti apa yang diinginkan yaitu hidup sehat. Setiap individu pasti mendambakan hidup yang sehat dan terhindar dari keadaan sakit. Namun, terkadang penyakit tidak dapat dielakkan karena individu saat ini sibuk dengan pekerjaannya sehingga sering memakan hidangan cepat saji, makanan yang tidak higienis, dan banyak hal yang dapat menyebabkan individu sakit.

Individu yang sedang mengalami sakit tentunya ingin sembuh agar dapat melakukan kegiatan sehari-hari. Oleh karena itu, individu membutuhkan perawatan dalam mengobati sakitnya. Pada saat individu sakit, individu memerlukan perlakuan khusus semacam pelayanan kesehatan. Individu yang sedang sakit memerlukan layanan yang baik dan dapat mempercepat penyembuhan. Hal semacam ini dapat ditemukan di rumah sakit. Rumah sakit adalah perusahaan yang melayani konsumen dalam bentuk jasa, biasanya konsumen yang dimaksud adalah pasien yang membutuhkan pelayanan kesehatan. Secara umum pelayanan rumah sakit terdiri dari pelayanan rawat jalan, rawat inap, maupun rawat bedah lengkap dengan fasilitasnya.

Kesembuhan individu dapat dipengaruhi oleh pelayanan kesehatan yang diberikan oleh pihak rumah sakit. Oleh karena itu, pelayanan kesehatan yang diberikan seharusnya dapat memenuhi kebutuhan pasien sebagai konsumen. Di era globalisasi saat ini terjadi pergeseran kekuasaan dalam pasar. Keadaan yang sebelumnya produsen menentukan produk atau jasa yang disediakan pasar, berubah menjadi konsumen yang menentukan produk atau jasa yang dibutuhkan dan harus dipenuhi oleh produsen. Hal ini disebabkan oleh semakin kritisnya tuntutan masyarakat akan standarisasi dan peningkatan mutu. Peningkatan standar hidup juga menyebabkan individu mengharapkan peningkatan standar kualitas jasa. Dengan demikian, sebuah perusahaan, dalam hal ini rumah sakit, harus selalu melengkapi dirinya agar senantiasa mendengarkan suara konsumen agar rumah sakit tersebut memiliki kemampuan memberikan respon terhadap setiap keinginan dan harapan konsumen. Untuk itu, keinginan dan harapan konsumen harus dipantau dengan cara mengadakan serangkaian pengamatan yang dilakukan secara terus-menerus.

Dengan terjadinya pergeseran pasar tersebut, menyebabkan para konsumen lebih memilih perusahaan atau rumah sakit yang dapat memenuhi harapan dan kebutuhannya sedangkan harapan dan kebutuhan konsumen terus-menerus berubah karena dibentuk kembali oleh setiap pengalaman hidup. Hal ini menyebabkan terjadinya persaingan antar perusahaan atau rumah sakit menjadi semakin ketat, sehingga mengharuskan sebuah rumah sakit untuk memiliki strategi pemasaran yang tepat agar dapat terus bertahan dan terus berkembang. Persaingan ini menyebabkan setiap rumah sakit berlomba-lomba untuk menciptakan kepuasan konsumen. 


\section{Landasan Teori}

\section{Kepuasan Konsumen}

Menurut J. Supranto (1997) untuk memenangkan persaingan perusahaan harus mampu memberikan kepuasan kepada para konsumen, misalnya dengan memberikan produk atau jasa yang mutunya lebih baik, harganya lebih murah, penyerahan produk atau jasa lebih cepat, dan pelayanan yang lebih baik dari pesaingnya. Produk atau jasa dengan mutu yang tidak bagus, harga yang mahal, dan penyerahan produk atau jasa yang lambat dapat membuat konsumen merasa tidak puas.

Menurut Zulian Yamit (2001:78) kepuasan konsumen adalah hasil (outcome) yang dirasakan atas penggunaan produk atau jasa, sama atau melebihi harapan yang diinginkan. Jadi kepuasan konsumen dapat diketahui setelah konsumen menggunakan produk dan jasa pelayanan. Dengan kata lain kepuasan konsumen merupakan hasil evaluasi konsumen setelah membandingkan apa yang dirasakan dengan apa yang diharapkan.

Lele dan Sheth (1995: 29) menyatakan bahwa kepuasan konsumen adalah kunci untuk mendapatkan keuntungan jangka panjang dan tetap menjaga kesenangan konsumen dan merupakan tugas setiap bisnis. Berdasarkan hasil penelitian Lele dan Sheth, perusahaan yang unggul dalam memberikan kepuasan konsumen memiliki ciri selalu berupaya memastikan bahwa tindakannya akan dapat menciptakan harapan konsumen dengan mementingkan janji-janji kepada konsumen tanpa peduli dengan biaya yang harus dikeluarkan.

Menurut Olson dan Dover (dalam Nasution, 2004:51) harapan konsumen merupakan keyakinan konsumen sebelum mencoba atau membeli suatu produk, yang dijadikan standar atau acuan dalam menilai kinerja produk tersebut. Kotler dan Armstrong (dalam Fandy Tjiptono, 2004:150) mengemukakan bahwa harapan konsumen dibentuk dan didasarkan oleh beberapa faktor, di antaranya pengalaman berbelanja di masa lampau, opini teman dan kerabat, serta informasi dan janji-janji perusahaan. Harapan konsumen adalah kunci pokok bagi setiap pelaku bisnis yang terlibat dalam kepuasan konsumen.

Suatu layanan jasa harus memiliki daya saing agar dapat menarik konsumen karena sebuah bisnis tidak dapat berlangsung tanpa konsumen. Keunggulan suatu layanan jasa terletak pada keunikan kualitas pelayanan jasa. Dengan demikian, kualitas pelayanan disesuaikan dengan manfaat yang dibutuhkan konsumen. Perusahaan atau rumah sakit yang menjadi kepercayaan konsumen adalah sebuah perusahaan atau rumah sakit yang mampu memberikan pelayanan dalam memenuhi harapan konsumen secara konsisten.

Di tengah persaingan usaha yang semakin kompetitif di antara para penyedia jasa kesehatan, kunci keberhasilan suatu perusahaan jasa kesehatan dalam menjalankan bisnisnya terletak pada kemampuan perusahaan tersebut dalam memberikan kepuasan kepada konsumen. Oleh karena itu, penelitian mengenai kepuasan konsumen penting untuk dilakukan.

Pentingnya kepuasan konsumen berkaitan dengan persaingan yang semakin ketat serta tingkat kerugian dan keuntungan suatu perusahaan. Khusus untuk alasan terakhir, keuntungan memang tidak selalu 
ditentukan oleh faktor kepuasan konsumen, tetapi juga ditentukan oleh kepercayaan dan kesetiaan konsumen terhadap suatu produk atau jasa yang dihasilkan oleh sebuah perusahaan. Beberapa faktor itu saling mempengaruhi karena di tengah ketatnya persaingan, kepuasan konsumen menjadi hal yang penting.

Merkouris et al (dalam Jurnal Manajemen Pelayanan Kesehatan, 2006: 178) menyebutkan bahwa pengukuran kepuasan pasien dapat digunakan sebagai alat untuk: 1) evaluasi kualitas pelayanan kesehatan, 2) evaluasi terhadap konsultasi intervensi dan hubungan antara perilaku sehat dan sakit, 3) membuat keputusan administrasi, 4) evaluasi efek dari perubahan organisasi, 5) administrasi staf, 6) fungsi pemasaran, dan 7) formasi etik profesional. Jadi, suatu pelayanan kesehatan harus selalu ditingkatkan agar kepuasan konsumen tercipta.

Kepuasan konsumen dapat diukur dari harapan dan kenyataan pelayanan yang diterima oleh konsumen. Bila yang diterima oleh konsumen jauh dari harapan maka konsumen akan kecewa atau tidak puas, sebaliknya konsumen akan merasa puas bahkan sangat puas bila yang diterima minimal sama bahkan melebihi apa yang diharapkan. Kepuasan konsumen hanya akan tercapai apabila perusahaan mampu memberikan pelayanan yang memuaskan. Kepuasan konsumen dapat menjadi kunci keberhasilan untuk mencapai keunggulan dalam persaingan bilamana perusahaan berhasil memberikan pelayanan yang lebih baik dan memuaskan dari pesaingnya. Sudah menjadi pendapat umum bahwa jika konsumen merasa puas dengan suatu produk atau jasa maka cenderung akan terus membeli atau menggunakannya. Bahkan ada pula konsumen yang memberitahukan orang lain tentang pengalaman mereka yang menyenangkan dengan produk atau jasa tersebut. Sebaliknya, jika konsumen merasa tidak puas, mereka cenderung beralih ke produsen lain, menyampaikan keluhan kepada penjual, atau bahkan menceritakan ketidakpuasannya itu pada konsumen lain.

Rumah Sakit Rawamangun Jakarta Timur sebagai suatu badan usaha yang bergerak dalam bidang pelayanan jasa kesehatan sangat memperhatikan kepuasan konsumennya. Semakin banyaknya kompetitor yang bermunculan membuat Rumah Sakit Rawamangun Jakarta Timur harus terus-menerus berusaha memberikan pelayanan yang terbaik agar kepuasan para konsumen tercipta dan tidak beralih ke kompetitor lain. Berdasarkan wawancara singkat dengan konsumen Rumah Sakit Rawamangun Jakarta Timur didapatkan beberapa keluhan mengenai kondisi fisik lingkungan rumah sakit seperti kebersihan dan penerangan di dalam rumah sakit. Oleh karena itu, peneliti tertarik untuk membuat rancangan strategi untuk meningkatkan kepuasan konsumen di Rumah Sakit Rawamangun Jakarta Timur.

\section{Metode Penelitian}

Metode pengambilan sampel yang digunakan dalam penelitian ini adalah dengan teknik accidental sampling. Sugiyono (2005) mengemukakan bahwa accidental sampling merupakan pengambilan sampel berdasarkan kebetulan, yaitu siapa saja yang secara 
kebetulan bertemu dengan peneliti dapat digunakan sebagai sampel bila dipandang individu yang kebetulan ditemui itu cocok sebagai sumber data. Teknik ini biasanya dilakukan karena keterbatasan waktu, tenaga, dan dana sehingga tidak dapat mengambil sampel yang besar dan jauh. Keuntungan dari teknik ini adalah terletak pada ketepatan peneliti memilih sumber data sesuai variabel yang diteliti (Suharsimi Arikunto, 2006: 203). Jumlah pasien rawat jalan yang dijadikan sampel penelitian sebanyak 98 orang.

Instrumen yang digunakan dalam penelitian ini yaitu berupa skala kepuasan konsumen. Skala ini mengungkap seberapa besar kepuasan konsumen pada subyek penelitian yang disusun sendiri oleh peneliti berdasarkan faktor-faktor kepuasan konsumen menurut Handi Irawan (2003) yang meliputi lima faktor yaitu faktor kualitas produk, harga, kualitas pelayanan, faktor emosional, dan kemudahan. Pada penelitian ini peneliti menggunakan skala model Likert dimana pilihan jawaban terdiri atas lima alternatif jawaban, yaitu sangat sesuai, sesuai, netral, tidak sesuai, dan sangat tidak sesuai serta terdiri dari 20 item favorable. Uji validitas dilakukan melalui program SPSS versi 24 dengan cara membandingkan Alpha Cronbach dan Alpha If Item Deleted. Jika Alpha If Item Deleted lebih kecil daripada Alpha Cronbach maka item tersebut dapat dikatakan valid. Sebaliknya jika Alpha If Item Deleted lebih besar daripada Alpha Cronbach maka item tersebut dapat dikatakan tidak valid atau gugur. Setelah dilakukan uji validitas, didapatkan 17 item valid dan 3 item tidak valid.

Teknik analisis data yang digunakan untuk mengetahui gambaran kepuasan konsumen dengan melihat distribusi data yang tersebar secara normal atau tidak normal dengan menggunakan uji normalitas. Selain itu, untuk mengetahui kriteria setiap responden berdasarkan tingkatan kepuasan konsumen, peneliti menggunakan kategorisasi data yang berdistribusi normal.

\section{Hasil dan Pembahasan Penelitian}

Uji reliabilitas instrumen diukur dengan menggunakan Alpha Cronbach melalui program SPSS versi 24. Hasil uji reliabilitas menunjukkan bahwa skala kepuasan konsumen memiliki koefisien reliabilitas sebesar 0,809 yang berarti skala kepuasan konsumen ini reliabel. Dari hasil koefisien reliabilitas tersebut, maka skala kepuasan konsumen tersebut telah memenuhi syarat reliabilitas dan hasilnya dapat dianalisis lebih lanjut.

Secara umum, hasil penelitian menunjukkan bahwa terdapat 46 orang atau $46,9 \%$ subyek yang memiliki kepuasan konsumen pada kategori tinggi, 45 orang atau $45,9 \%$ subyek memiliki kepuasan konsumen pada kategori sedang, dan 7 orang atau $7,1 \%$ subyek memiliki kepuasan konsumen pada kategori rendah.

Gambaran Kepuasan Konsumen Tiap Poli

\section{Poli Anak}

Hasil penelitian menunjukkan bahwa pada poli anak terdapat 18 orang atau $58,1 \%$ subyek yang memiliki kepuasan konsumen 5 | Psychophedia Jurnal Psikologi Universitas Buana Perjuangan Karawang 
pada kategori tinggi, 12 orang atau $38,7 \%$ subyek memiliki kepuasan konsumen pada kategori sedang, dan 1 orang atau 3,2\% subyek memiliki kepuasan konsumen pada kategori rendah.

\section{Poli Kebidanan}

Hasil penelitian menunjukkan bahwa pada poli kebidanan terdapat 6 orang atau $31,5 \%$ subyek yang memiliki kepuasan konsumen pada kategori tinggi, 12 orang atau 63,2\% subyek memiliki kepuasan konsumen pada kategori sedang, dan 1 orang atau 5,3\% subyek memiliki kepuasan konsumen pada kategori rendah.

\section{Poli Umum}

Hasil penelitian menunjukkan bahwa pada poli umum terdapat 10 orang atau $45,5 \%$ subyek yang memiliki kepuasan konsumen pada kategori tinggi, 10 orang atau 45,5\% subyek memiliki kepuasan konsumen pada kategori sedang, dan 2 orang atau $9 \%$ subyek memiliki kepuasan konsumen pada kategori rendah.

\section{Poli Penyakit Dalam}

Hasil penelitian menunjukkan bahwa pada poli penyakit dalam terdapat 9 orang atau $50 \%$ subyek yang memiliki kepuasan konsumen pada kategori tinggi, 6 orang atau 33,3\% subyek memiliki kepuasan konsumen pada kategori sedang, dan 3 orang atau $16,7 \%$ subyek memiliki kepuasan konsumen pada kategori rendah.

\section{Poli Gigi}

Hasil penelitian menunjukkan bahwa pada poli gigi terdapat 1 orang atau $20 \%$ subyek yang memiliki kepuasan konsumen pada kategori tinggi dan 4 orang atau $80 \%$ subyek memiliki kepuasan konsumen pada kategori sedang.

\section{Poli THT}

Hasil penelitian menunjukkan bahwa pada poli THT terdapat 2 orang atau 66,7\% subyek yang memiliki kepuasan konsumen pada kategori tinggi dan 1 orang atau 33,3\% subyek memiliki kepuasan konsumen pada kategori sedang.

\section{Sumbangan Tiap Faktor terhadap} Kepuasan Konsumen

Adapun gambaran sumbangan dari faktor kualitas produk, harga, kualitas pelayanan, faktor emosional, dan kemudahan terhadap kepuasan konsumen di Rumah Sakit Rawamangun Jakarta dapat dilihat pada tabel di bawah ini:

\begin{tabular}{cc}
\hline Faktor & Sumbangan \\
\hline Kualitas produk & $1,6 \%$ \\
\hline Harga & $5,8 \%$ \\
\hline Kualitas pelayanan & $1,4 \%$ \\
\hline Faktor emosional & $9,4 \%$ \\
\hline Kemudahan & $81,9 \%$ \\
\hline
\end{tabular}

Berdasarkan data dapat diketahui bahwa faktor utama yang menimbulkan kepuasan konsumen adalah kemudahan yang memberikan sumbangan sebesar $81,9 \%$ terhadap kepuasan konsumen, hal ini dapat terjadi karena konsumen merasa mudah mendapatkan informasi dan mudah dalam proses administrasi sehingga konsumen merasa nyaman melakukan pemeriksaan kesehatan di rumah sakit ini. Untuk faktor 
kedua adalah faktor emosional yang memberikan sumbangan sebesar 9,4\% terhadap kepuasan konsumen, hal ini terjadi dikarenakan konsumen merasa bangga melakukan pemeriksaan kesehatan di rumah sakit ini. Faktor ketiga adalah harga dengan sumbangan sebesar 5,8\% terhadap kepuasan konsumen, ini terjadi dikarenakan konsumen merasa biaya pemeriksaan kesehatan di rumah sakit ini terjangkau dan biaya yang dikeluarkan sebanding dengan pelayanan yang didapatkan. Untuk faktor keempat adalah kualitas produk yang memberikan sumbangan sebesar $1,6 \%$ terhadap kepuasan konsumen. Sumbangan pada faktor kualitas produk tergolong rendah terhadap kepuasan konsumen sehingga kualitas produk masih dirasakan kurang oleh konsumen. Pada faktor kelima, kualitas pelayanan memberikan sumbangan terkecil terhadap kepuasan konsumen yaitu sebesar $1,4 \%$. Hal ini dapat menjadi perhatian dikarenakan konsumen merasa pelayanan yang diberikan pihak rumah sakit masih kurang.

\section{Kesimpulan}

Berdasarkan hasil penelitian yang diperoleh dari 98 orang sampel pengguna jasa rawat jalan di Rumah Sakit Rawamangun Jakarta, maka diperoleh 46 orang atau 46,9\% subyek yang memiliki kepuasan konsumen pada kategori tinggi, 45 orang atau 45,9\% subyek memiliki kepuasan konsumen pada kategori sedang, dan 7 orang atau 7,1\% subyek memiliki kepuasan konsumen pada kategori rendah. Selain itu, faktor utama yang menimbulkan kepuasan konsumen adalah faktor kemudahan yang memberikan sumbangan sebesar 81,9\% terhadap kepuasan konsumen.

\section{Kepustakaan}

Fandy Tjiptono. (2004). Manajemen jasa. Yogyakarta: Andi Offset.

Handi Irawan. (2003). Indonesia customer satisfaction: membedah strategi kepuasan pelanggan merek pemenang ICSA. Jakarta: PT. Elex Media Komputindo.

J. Supranto. (1997). Pengukuran tingkat kepuasan pelanggan. Jakarta: PT. Rineka M.

Lele, M dan Sheth, J.N. (1995). Pelanggan kunci keberhasilan. Jakarta: Gramedia.

Sution, M.N. (2004). Manajemen jasa terpadu. Bogor: Ghalia Indonesia.

Sugiyono. (2005). Statistika untuk Penelitian. Bandung: Alfabeta.

Suharsimi Arikunto. (2006). Prosedur penelitian: suatu pendekatan praktek. Jakarta: PT. Rineka Cipta.

Zulian Yamit. (2001). Manajemen kualitas produk dan jasa. Yogyakarta: Ekonisia 